\title{
3 Research Square \\ Self-fed Supplements of Low and Medium Intake for Beef Steers Finished on Pasture
}

Saimon de Souza Souza

Universidade Tecnologica Federal do Parana

Régis Luis Missio

Universidade Tecnologica Federal do Parana

Wagner Paris ( $\nabla$ wagparis@yahoo.com.br)

Universidade Tecnológica Federal do Paraná https://orcid.org/0000-0003-3128-7844

Jefferson Felipe Cavazzana

Universidade Tecnologica Federal do Parana

Marcelo Machado Severo

Universidade Tecnologica Federal do Parana

Julia Maria Poggere

Universidade Tecnologica Federal do Parana

Luis Fernando Glasenapp de Menezes

Universidade Tecnologica Federal do Parana

Olmar Antônio Denardin Costa

Universidade Tecnologica Federal do Parana

\section{Research Article}

Keywords: animal performance, forage digestibility, animal intake, ingestive behavior

Posted Date: June 7th, 2021

DOI: https://doi.org/10.21203/rs.3.rs-548103/v1

License: (c) (i) This work is licensed under a Creative Commons Attribution 4.0 International License.

Read Full License 


\section{Abstract}

The obstacles of using supplementation are related to the cost and labor. Self-fed supplements of low and medium intake can be an option to overcome these problems. However, the nutritive value and pasture yield are crucial to finding the right composition and amount of supplement. We evaluated productive responses of steers receiving self-fed supplements of low and medium intake on Aruana grass pasture. The animal performance, ingestive behavior, and pasture characteristics were evaluated in a completely randomized design with three treatments and three replicates. Twenty-four Aberdeen Angus steers were used as the tester animals. The dry matter intake and nutrient digestibility were evaluated in a $3 \times 3$ double Latin square repeated over time. The treatments consisted of mineral salt (control), supplementation for intake of $1.5 \mathrm{~g} / \mathrm{kg}$ body weight (low-intake), and supplementation for intake of 4.0 $\mathrm{g} / \mathrm{kg}$ body weight (medium-intake). The supplements did not influence the pasture characteristics and ingestive behavior, except the number of bites/day that was higher for the low-intake. Dry matter digestibility and forage intake were not affected by the supplementation, but the total dry matter intake increased for the medium-intake. The average daily gain, stocking rate, and fat thickness gain were higher for the medium-intake. The self-fed supplements of medium-intake increase the total dry matter intake, maximizing the performance of steers on Aruana grass.

\section{Introduction}

The seasonal production in tropical pastures makes it difficult to maintain the growth curve of the animals. In general, the growing phase for cattle in tropical regions covers periods of low supply and quality of forage (cool season) and others with better quality and availability (warm season). Feeding strategies must be used to optimize animal performance and the production system. In this context, the choice of strategy depends mainly on the supply of amino acids and energy-yielding substrates to be delivered to the tissues, up to the genetic limit for protein synthesis, which is probably never reached in animals consuming only tropical pastures (Poppi and McLennan 1995).

During the warm season, when forages present levels of nitrogenous compounds above the minimum recommended for full activity of the bacteria that use the structural carbohydrates, supplementation with starch and nitrogen can improve digestion and nitrogen retention (Lazzarini et al., 2016). In addition, animals coming into the cool season tend to exhibit compensatory growth and the energetic-protein supplementation often improves weight gain (Poppi and McLennan 1995).

The high cost and (or) lack of labor for cattle supplementation are not recent as well as the interest in self-fed supplements (Kunkle et al., 2000). However, the results of these supplements are inconsistent. On one hand, there are indications of high variability in supplement intake (Brokaw et al., 2002) and adverse effects on animal performance (Williams et al., 2018). On the other hand, some research does not show any disadvantages of their use (Schauer et al., 2004; Moraes et al., 2017). Yet, the information about selffed supplements for cattle grazing tropical grasses is incipient. 
Therefore, we hypothesized that self-fed supplements of low and medium intake could increase productive responses of beef cattle on tropical pastures. Thus, this study aimed to evaluate the productive responses of steers receiving self-fed supplements of low and medium intake on Aruana grass during the warm season.

\section{Materials And Methods}

\section{Local and treatments characterization}

All procedures and protocols in this experiment were approved by the Committee of Ethics on Animal Use (CEAU) of the Universidade Tecnológica Federal do Paraná (CEAU number 2016-002), located at 2544'S and $53^{\circ} 04^{\prime} \mathrm{W}$.

The experimental design used was completely randomized, with three treatments (supplements) and three replicates (paddocks). The treatments were: mineral salt supplementation (mineral salt), energeticprotein supplementation formulated for ingestion of $1.5 \mathrm{~g} / \mathrm{kg}$ body weight (low-intake), and $4.0 \mathrm{~g} / \mathrm{kg}$ body weight (medium-intake). These supplements were composed of corn meal, soybean meal, mineral salt, common salt, feed grade urea, and calcitic limestone (Table 1). The supplements were provided ad libitum once a week, we estimated the orts at $10 \%$ of voluntary intake, which was monitored weekly by weighing the offered supplements and orts. The animals had free access to water. 
Table 1

Dry matter composition of supplements and ingredients of the diet of steers receiving self-fed supplements on Aruana grass pasture.

\begin{tabular}{|c|c|c|c|c|c|}
\hline \multirow[t]{3}{*}{ Items } & \multicolumn{3}{|c|}{ Supplements } & \multirow[t]{3}{*}{ Corn meal } & \multirow[t]{3}{*}{ Soybean meal } \\
\hline & Salt & Low & Medium & & \\
\hline & Mineral $^{1}$ & intake $^{2}$ & intake $^{3}$ & & \\
\hline Corn meal§§ & - & 493 & 670 & - & - \\
\hline Soybean meal§§ & -- & 164 & 138 & - & - \\
\hline Mineral salt ${ }^{\star} \S \S$ & 1000 & 133 & 67.8 & - & - \\
\hline Common salt & - & 166 & 79.1 & - & - \\
\hline Feed grade urea§§ & - & 33.1 & 33.9 & - & - \\
\hline Calcitic limestone $\S \S$ & - & 11.1 & 11.3 & - & - \\
\hline Dry matter§ & 1000 & 960 & 939 & 859 & 874 \\
\hline Ash§§ & 1000 & 336 & 170 & 13.7 & 67.1 \\
\hline Crude protein§§ & - & 243 & 284 & 99.2 & 468 \\
\hline Neutral detergent fiber $\S \S$ & - & 148 & 199 & 102 & 124 \\
\hline Non-fibrous carbohydrates $\S \S$ & - & 252 & 322 & 756 & 315 \\
\hline \multicolumn{6}{|c|}{ 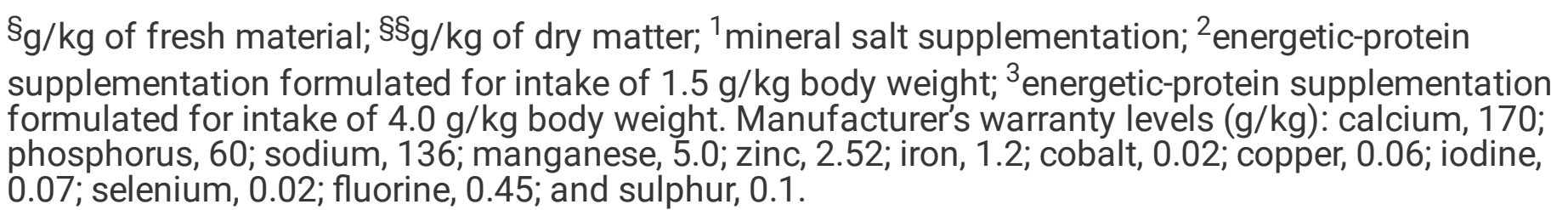 } \\
\hline
\end{tabular}

The experimental area had 4.5 ha of Panicum maximum Jacq 'Aruana' in a soil classified as clay Latosol, divided into nine paddocks ( $0.5 \mathrm{ha}$ ). The seeding of the Aruana grass (September 2015) occurred in the interweaving of a corn crop for silage, by no-tillage, using $15 \mathrm{~kg} / \mathrm{ha}$ of seeds. The base fertilization (300 $\mathrm{kg} / \mathrm{ha}$ ) was applied during the planting with a formulated fertilizer 10-20-10 ( $\left.\mathrm{N}, \mathrm{P}_{2} \mathrm{O}_{5}, \mathrm{KCl}\right)$. After harvesting the corn for ensiling, the area was left for pasture growth. The nitrogen was applied as urea (150 kg N/ha) divided into three applications (12/16/2016, 02/03/2017, and 03/14/2017).

The grazing started in mid-October and the experimental period started in 12/04/2016. The grazing cycle lasted 120 days ( +15 days for adaptation), until 04/18/2017. We used 36 steers during the grazing cycle. From this total, 24 steers of the Aberdeen Angus breed were the testers animals, and they remained on the pasture throughout the experimental period. The animals came from the same herd and calving season, 
they were 15 months of age and had $364.8 \pm 21.7 \mathrm{~kg}$ of body weight (BW). At the beginning of the experiment, all animals were submitted to endo and ectoparasites control.

The pasture was managed to maintain between 40 and $50 \mathrm{~cm}$ height, and it was measured weekly in 25 spots of each paddock. The pasture was managed under a continuous stocking rate, with the put-andtake adjustment method (Mott and Lucas 1952) and 15 days of intervals. Three tester animals were used in each paddock, except in one paddock of each treatment that we used two tester animals. The forage allowance was calculated as described by Sollenberger et al. (2005), according to the equation: FA = $\left(\mathrm{FM}_{\text {mean }}\right) /(\mathrm{kg} \mathrm{LW} / \mathrm{ha})$, where: FA: Forage allowance; FM: forage mass, calculated as ( $\left(\mathrm{FM}_{\text {cut } 1}+\mathrm{FM}_{\text {cut }}\right.$ 2)/2); and LW: live weight. The stocking rate (SR) was calculated as the sum of the tester animals' body weight, corrected by the area size added to the weight of the grazing-height regulator animals, taking into account the number of days that the regulators remained in each paddock.

Forage mass (FM) was estimated every 31 days (Barthram 1985) in three sites $\left(1 \mathrm{~m}^{2}\right)$. The daily forage accumulation rate (DFAR) was measured using three grazing exclusion cages per paddock. All samples were cut at ground level. The forage samples for chemical analysis were obtained by manual grazing simulation. The pasture samples were dried in a forced air oven at $55^{\circ} \mathrm{C}$ for $72 \mathrm{~h}$.

For chemical analysis, all samples were ground in a Wiley-type mill fitted with a 1-mm-sieve. We determined the contents of dry matter (DM), ash, organic matter (OM), crude fat (CF), and crude protein (CP) by the AOAC (1993); the neutral detergent fiber was determined by Van Soest et al. (1991) method adapted by the ANKOM 2000 methodology (ANKOM 2000 Fiber Analyzer, ANKOM Technology Corporation, Fairport, NY, USA). The non-fibrous carbohydrates (NFC) content was determined according to Sniffen et al. (1992): NFC (g/ kg) $=1000-(C P+E E+a s h+N D F)$.

The animal behavior assessments were conducted during daytime periods of 13 hours ( 5 am to $7 \mathrm{pm}$ ), totaling two evaluations with 60 days of interval. We observed two animals per paddock, and their rumination time, grazing time, and other activities were evaluated. The grazing time was obtained by the direct observation (Penning and Rutter 2004), recording the most frequent activity at the end of each 10 min interval, including the time spent in rumination and idleness. Other activities such as rest, supplement intake, drinking, and social behaviors were grouped.

The time spent by the animal to perform 20 bites was evaluated to calculate the bite rate (Hodgson 1982). The ingestive and rumination behaviors, and displacement pattern were measured six times a day - three times in the morning and three in the afternoon. The observed variables were: time spent to complete 10 feeding stations, number of steps between stations, number of chews per bolus, and rumination time per bolus. Displacement rate (steps/min) and daytime number of feeding stations were estimated from these data. The number of bites per station was calculated by the ratio between the number of daytime bites and feeding stations. The number of bites per day was obtained by multiplying the bite rate and grazing time. The number of stations per minute was calculated by dividing the number of daytime stations by grazing time. 
The average daily gain (ADG) during the entire grazing period was evaluated by two weighings, one at the beginning and one at the end of the experimental period. The animals fasted for 14 hours before the weighings. The ADG was calculated as the difference between the initial (IBW) and final weight (FBW) divided by the number of days in grazing. At the time of the initial and final weighings, the tester steers were evaluated for subcutaneous fat thickness (SFT) between the 11th and 12th ribs by an ultrasound device (Pie Medical - Scanner 200 VET, model 51B04UM02). The subcutaneous fat thickness gain (SFTG) was calculated as the difference between the initial and final SFT divided by the number of days in grazing. The average weight gain per area (AWG) was obtained as the product of the testers' daily gain and the evaluation days (Euclides et al., 2016), added to the gain of the regulators corrected by the time in the paddock.

We used a Latin square design with three Aberdeen Angus steers for the evaluation of the intake and diet digestibility, the animals were 15 months of age and had $296.5 \pm 8 \mathrm{~kg}$ of body weight. They were managed together with the other animals of the experiment, being also submitted to endo and ectoparasites control at the beginning of the experimental period, and their effects on the SR were considered. The dry matter intake (DMI) was determined by: Intake $(\mathrm{kg} /$ day) = fecal production $(\mathrm{kg}$ $\mathrm{DM} /$ day)/1-diet DM digestibility. The forage intake was determined by the difference between the total intake and supplement intake.

Titanium dioxide $\left(\mathrm{TiO}_{2}\right)$ was used as an external marker to estimate fecal production. $\mathrm{TiO}_{2}$ was supplied in the daily amount of $10 \mathrm{~g} / \mathrm{steer}(4 \mathrm{pm})$ for 12 days. The fecal collection occurred directly from the animals' rectum, twice a day (12 pm and 4 pm) as proposed by Penning and Rutter (2004). In each evaluation period (19 days) the animals had seven days for adaptation to the supplements. After each evaluation period, a composite feces sample per animal was obtained and the $\mathrm{TiO}_{2}$ concentration was determined by uv-vis spectrophotometry (Myers et al., 2004). Fecal production (FP, kg of DM/day) was determined as: $\mathrm{FP}=$ intake $\mathrm{TiO}_{2} / \mathrm{fecal} \mathrm{TiO}_{2}$. The apparent digestibility $(\mathrm{AD}, \mathrm{g} / \mathrm{kg}$ of $\mathrm{DM})$ was determined as: $A D=$ (nutrient intake - nutrient excreted)/nutrient intake.

A completely randomized design was used for the evaluation of animal performance, ingestive behavior, and forage characteristics. For the evaluation of intake and forage digestibility, we used a $3 \times 3$ double Latin square ( 3 treatments and 3 periods). The data were analyzed using a mixed model methodology (Littell et al., 2006) incorporating the fixed effect (treatment) and random effects (for the Latin square, we considered animal, period, and the treatment*period interaction as random effects) into the model. We used the Tukey-Kramer test for comparison between means $(a=0.05)$. The model used for variables that followed the completely randomized design was represented by:

$Y_{i j k}=\mu+T_{i}+\beta_{1} X_{i j}+e_{i j k}$

In which $Y_{i j k}$ is the dependent variable, $\mu$ is a constant, $T i$ is the effect of diets, $\beta_{1} X_{i j}=$ is the effect of the covariates (IBW and SFT), and $\mathrm{e}_{\mathrm{ijk}}$ is the residual experimental error. 
For the Latin square design, the model was represented by:

$Y_{i j k}=\mu+T_{i}+P_{j}+A_{k}+T P_{i j}+e_{i j k}$

In which $Y_{i j k}$ is the dependent variable, $\mu$ is a constant, $T i$ is the effect of diets, $P_{j}$ is the effect of period, $A_{k}$ is the animal effect, $\mathrm{TP}_{\mathrm{ij}}$ is the effect of interaction between treatment and period, $\mathrm{e}_{\mathrm{ijk}}$ is the residual experimental error.

\section{Results}

\section{Pasture characteristics}

The supplementation (Table 2) did not influence $(P>0.05)$ the sward height, forage mass, forage accumulation, forage allowance, and stocking rate. The supplements did not influence $(P>0.05)$ the pasture contents of DM, CP, and NDF. Similarly, the forage contents of DM, OM, NDF apparent digestibility, and total digestible nutrients were not affected by the treatments. The crude protein apparent digestibility (CPAD) was higher without any supplementation. 
Table 2

Yield parameters and nutritive value of the diet of steers receiving self-fed supplements on Aruana grass pasture.

\begin{tabular}{|c|c|c|c|c|c|}
\hline \multirow[t]{3}{*}{ Items } & \multicolumn{3}{|l|}{ Diets } & \multirow[t]{3}{*}{ SEM $^{4}$} & \multirow[t]{3}{*}{ P-value } \\
\hline & Mineral & Low & Medium & & \\
\hline & Salt ${ }^{1}$ & intake $^{2}$ & intake $^{3}$ & & \\
\hline Sward height (cm) & 45.0 & 46.0 & 45.0 & 0.75 & 0.76 \\
\hline Stocking rate (ton/ha) & 2.36 & 2.54 & 2.92 & 0.11 & 0.12 \\
\hline Forage mass ${ }^{£}$ & 7.75 & 7.48 & 7.78 & 0.14 & 0.35 \\
\hline Forage accumulation ${ }^{£ £}$ & 94.0 & 123.0 & 130.0 & 12.0 & 0.15 \\
\hline Forage allowance $e^{£ £ f}$ & 3.29 & 2.94 & 2.66 & 0.002 & 0.45 \\
\hline Dry matter§ & 281 & 271 & 271 & 1.03 & 0.46 \\
\hline Crude protein $\S \S$ & 216 & 212 & 214 & 2.77 & 0.78 \\
\hline Neutral detergent fiber§§ & 613 & 602 & 611 & 3.40 & 0.24 \\
\hline Dry matter digestibility§§ & 540 & 540 & 530 & 0.41 & 0.52 \\
\hline Organic matter digestibility§§ & 600 & 590 & 580 & 4.63 & 0.43 \\
\hline Crude protein digestibility§§ & $680 a$ & $630 \mathrm{~b}$ & $620 \mathrm{~b}$ & 13.2 & 0.02 \\
\hline Neutral detergent fiber digestibility§§ & 590 & 620 & 610 & 7.24 & 0.19 \\
\hline Total digestible nutrients§§ & 553 & 546 & 535 & 4.15 & 0.24 \\
\hline \multicolumn{6}{|c|}{ 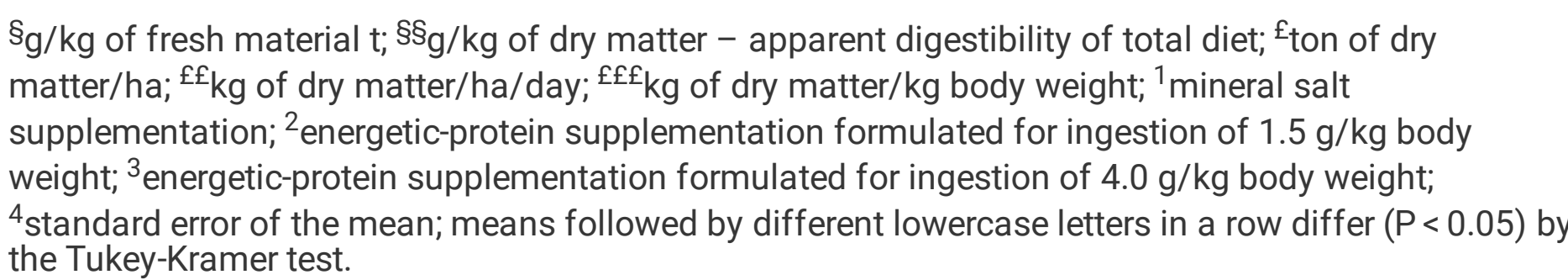 } \\
\hline
\end{tabular}

\section{Animal performance and ingestive behavior}

The medium-intake presented the highest $(P<0.05)$ supplement intake $(\mathrm{kg} / \mathrm{day}$ and \%BW), intermediate values were observed for low-intake, and the lowest values for the mineral supplementation (Table 3). The forage intake was not changed $(P>0.05)$ by the supplements. The total DMI $(\mathrm{kg} / \mathrm{day})$ was higher $(P$ $=0.03$ ) for medium-intake than the control treatment, without any difference for other comparisons 
between supplements. However, total DMI expressed as \%BW was higher $(P=0.013)$ for medium-intake than other supplements, which did not differ for this characteristic.

Table 3

Intake and animal performance of steers receiving self-fed supplements on Aruana grass pasture.

\begin{tabular}{|c|c|c|c|c|c|}
\hline \multirow[t]{3}{*}{ Items } & \multicolumn{3}{|l|}{ Diets } & \multirow[t]{3}{*}{ SEM $^{4}$} & \multirow[t]{3}{*}{ P-value } \\
\hline & Mineral & Low intake ${ }^{2}$ & Medium & & \\
\hline & \multicolumn{2}{|l|}{ Salt ${ }^{1}$} & intake $^{3}$ & & \\
\hline Supplement intake $§$ & $0.04 \mathrm{c}$ & $0.43 b$ & $1.13 a$ & 0.49 & $<0.01$ \\
\hline Supplement intake $e^{£ £ £}$ & $0.15 c$ & $1.50 \mathrm{~b}$ & $3.95 a$ & 0.36 & $<0.01$ \\
\hline Forage intake $\S$ & 6.21 & 6.48 & 6.44 & 0.21 & 0.64 \\
\hline Forage intake $£ £ £$ & 21.4 & 22.3 & 22.9 & 0.64 & 0.32 \\
\hline Dry matter intake $\mathrm{e}^{£}$ & $6.24 b$ & $6.91 a b$ & $7.57 a$ & 0.29 & 0.03 \\
\hline Dry matter intake $e^{£ £ £}$ & $21.6 b$ & $23.7 b$ & $26.8 \mathrm{a}$ & 0.98 & 0.01 \\
\hline Initial body weight* & 311 & 299 & 301 & 6.13 & 0.38 \\
\hline Final body weight* & 386 & 370 & 401 & 5.49 & 0.13 \\
\hline Final subcutaneous fat thickness ${ }^{\star \star}$ & 3.00 & 2.10 & 3.60 & 0.31 & 0.09 \\
\hline Average daily gain§ & $0.62 b$ & $0.59 b$ & $0.83 a$ & 0.04 & $<0.01$ \\
\hline Subcutaneous fat thickness gain ${ }^{\star \star}$ & $0.95 b$ & $0.80 \mathrm{~b}$ & $2.67 a$ & 0.36 & 0.03 \\
\hline Weight gain per area ${ }^{\zeta}$ & $398 b$ & $404 b$ & $659 a$ & 12.6 & $<0.01$ \\
\hline \multicolumn{6}{|c|}{ 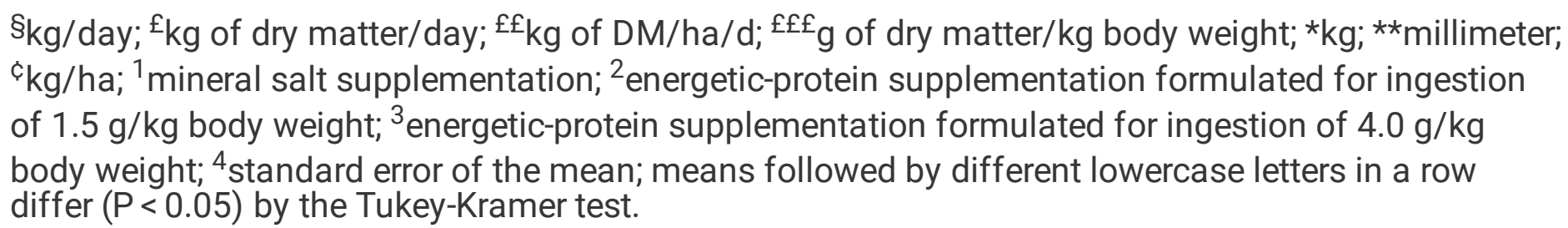 } \\
\hline
\end{tabular}

The final body weight and subcutaneous fat thickness did not differ $(P>0.05)$ between supplements (Table 3). However, the ADG, SFTG, and AWG were higher $(P<0.05)$ for the medium-intake supplement.

Grazing, rumination, and other activities time were not affected $(P>0.05)$ by the supplements (Table 4). Likewise, the number of diurnal stations, time per feeding station, steps per minute, bite rate (bites $/ \mathrm{min}$ ), and number of bites per station were not $(P>0.05)$ affected by the supplements. Chewing time per bolus and number of chewing per bolus were higher $(P<0.05)$ for medium-intake compared to the control supplement, with intermediate values for the low-intake. 
Table 4

Ingestive behavior and displacement pattern of steers receiving self-fed supplements on Aruana grass pasture.

\begin{tabular}{|c|c|c|c|c|c|}
\hline \multirow[t]{3}{*}{ Items } & \multicolumn{3}{|l|}{ Diets } & \multirow[t]{3}{*}{ SEM $^{4}$} & \multirow[t]{3}{*}{ P-value } \\
\hline & & Low intake ${ }^{2}$ & & & \\
\hline & \multicolumn{2}{|l|}{ Salt ${ }^{1}$} & intake $^{3}$ & & \\
\hline Grazing§ & 400 & 443 & 388 & 15.5 & 0.31 \\
\hline Rumination§ & 95.8 & 102 & 132 & 17.9 & 0.67 \\
\hline Other activities $\S$ & 328 & 279 & 292 & 17.0 & 0.51 \\
\hline Diurnal stations $\S \S$ & 19.5 & 23.9 & 18.9 & 107 & 0.10 \\
\hline Number of stations ${ }^{f}$ & 4.89 & 5.38 & 4.88 & 0.17 & 0.09 \\
\hline Displacement rate $£^{£ £}$ & 8.40 & 8.62 & 7.63 & 0.47 & 0.64 \\
\hline Bite rate $\mathrm{fff}^{\mathrm{f}}$ & 32.6 & 35.8 & 30.4 & 1.53 & 0.36 \\
\hline Number of bites per station & 6.99 & 6.83 & 6.35 & 0.48 & 0.85 \\
\hline Number of chews per bolus & $34.8 b$ & $40.9 a b$ & $45.0 \mathrm{a}$ & 1.61 & 0.04 \\
\hline Chewing rate* & $34.8 b$ & $40.0 \mathrm{ba}$ & $46.0 \mathrm{a}$ & 1.83 & 0.04 \\
\hline \multicolumn{6}{|c|}{ 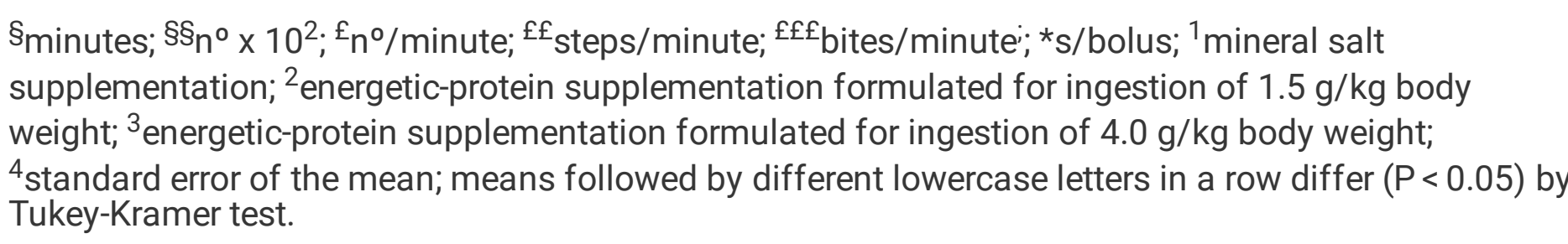 } \\
\hline
\end{tabular}

\section{Discussion}

The mechanism of replacing the pasture with the supplied energetic-protein supplementation was not observed in our study. Thus, the similar pasture conditions between treatments enabled a similar stocking rate, forage allowance, and forage intake. In this context, grazing is one of the main factors of the structure and composition of grassland ecosystems (Dumont et al., 2012). The lack of a significant effect of supplementation on ingestive behavior and the search for forage are related to the chemical composition of the ingested forage (Table 2). The main feed factors that affect intake are the contents of dry matter and fiber, which consequently affect the diet's digestibility (Koscheck, et al., 2013).

The equal digestibility of the diet can be attributed to the similar chemical composition of the pasture and to the DM intake. Meanwhile, the protein digestibility, which decreased, may be related to the increase in the intake of smaller particles through the supply of energetic-protein supplements. The increase in the 
intake level can accelerate the passage rate, which means a shorter residence time of particles in the rumen, reducing the digestibility of the diet, as suggested by Missio et al. (2012). In addition, according to Kunkle et al. (2000), the extra-salt in supplements can increase water consumption and may result in increased ruminal protein passage and escape rates.

In general, energetic-protein supplementation benefit forage digestibility in tropical pastures (Socreppa et al., 2017). The decrease of forage intake and its digestibility by supplementation in grazing cattle occur when non-fibrous carbohydrates in supplements are offered above $0.4 \%$ BW (maximum of $0.3 \%$ BW in this study) as reviewed by Kunkle et al. (2000). The positive effect of energetic-protein supplementation is due to the improved energy/protein ratio, which results in increased microbial protein synthesis and digestion rates (Detmann et al., 2014). Socreppa et al. (2017) report that $13 \mathrm{mg} / \mathrm{dL} \mathrm{NH}_{3}-\mathrm{N}$ are required to maximize the voluntary forage intake, which corresponds to approximately $120 \mathrm{~g} / \mathrm{kg}$ of protein on DM. In our study, there was no measurement of $\mathrm{NH}_{3}-\mathrm{N}$, but the amount of supplement was not sufficient to influence the forage intake.

Pastures composed of $\mathrm{C}_{4}$ grasses tend to present higher biomass production and nutritional value in warm periods (September to April in Southern Brazil). This reflects in the animal performance, however, the use of basal forage during this period is not considered optimal (Detmann et al., 2014), because there is a nutritional imbalance in tropical pastures that is characterized by low availability and degradability of soluble carbohydrates and protein. Therefore, there is an unused ADG potential that can be achieved through supplementation (Poppi and McLennan 1995). In our study, this animal growth potential was only achieved in the medium-intake supplementation ( $+0.23 \mathrm{~kg} /$ day $)$, and it can be observed by the difference in total DMI.

The increase in fat deposits without affecting ADG during the growing phase can be an important tool to improve the animals' carcass quality, especially those finished on pasture. The animals with the highest amount of supplementation presented a higher fat thickness and ADG, demonstrating that $4 \mathrm{~g} / \mathrm{kg} \mathrm{BW}$ of an energetic-protein supplementation may be a viable option in the growing phase for cattle.

The supplementation did not show any influence on the animals' activities. According to Hodgson (1990), the daily activities are mutually exclusive, in which the increase in rumination and idleness implies a decrease in feeding time. As mentioned before, the supplementation was not sufficient to influence the forage intake by the animals, which is reinforced by the absence of variation in the behavioral activities in the search for forage. The rumination pattern may be related to the dry matter intake, suggesting that the animals improved the rumination efficiency when they increased the intake. Therefore, as animals consume more roughage, they may present some increase in the time for ruminating the bolus and mandibular movement rate. This may have contributed to the high ADG.

The supply of self-fed supplements with $4 \mathrm{~g} / \mathrm{kg}$ body weight increases the dry matter intake, with maximization of the performance of steers on Aruana grass. Thus, the medium-intake supplementation allow increasing the animals' individual performance and stocking rate in tropical pastures, with a $60 \%$ 
increase in live weight gain per area during the growing phase, being possible to reach productive rates similar to intensive production systems. In addition, operating costs can be reduced by using self-fed supplements.

\section{Declarations}

\section{Statement of animal rights}

All procedures and protocols in this experiment were approved by the Committee of Ethics on Animal Use (CEAU) of the Universidade Tecnológica Federal do Paraná (CEAU number 2016/002)

\section{Conflict of interest statement}

The authors declare no conflicts of interest.

\section{Funding}

This study was financed in part by the Coordenação de Aperfeiçoamento de Pessoal de Nível Superior Brasil (CAPES) - Finance Code 001.

\section{Conflicts of interest/Competing interests}

Not applicable

\section{Availability of data and material}

The datasets generated during and/or analysed during the current study are available from the corresponding author on reasonable request.

\section{Code availability}

Not applicable

\section{Ethics approval}

This study was approved by Ethics Committee on Animal Use of the Universidade Tecnológica Federal do Paraná - Brazil, (number 2016/002)

\section{Consent to participate}

Not applicable

\section{Consent for publication}

Not applicable 


\section{Author contributions}

All authors contributed to the study conception and design. Material preparation, data collection and analysis were performed by Saimon de Souza e Souza, Wagner Paris and Régis Luis Missio. The first draft of the manuscript was written by Saimon Souza e Souza and all authors commented on previous versions of the manuscript. All authors read and approved the final manuscript.

\section{Acknowledgments}

This study was financed in part by the Coordenação de Aperfeiçoamento de Pessoal de Nível Superior Brasil (CAPES) - Finance Code 001.

\section{References}

1. AOAC, 1993. Official Methods of Analysis, 15th ed. Association of Official Analytical Chemists. AOAC (Washington, DC)

2. Bae, D.H., Welch, J., Smith, A.M., 1981. Efficiency of mastication in relation to hay intake by cattle. Journal of Animal Science, 52, 1371-1375. doi: 10.2527/jas1981.5261371x

3. Barthram, G.T., 1985. Experimental techniques: The HFRO sward stick. In: Alcock, M.M., (eds), Biennial report of the Hill Farming Research Organization. Midlothian: Hill Farming Research Organization, 29-30.

4. Brokaw, L., Hess, B.W., Bartle, S.J., Landeis, R.D., Alexander, B.M., Moss, G.E., 2002. Effects of handfed versus self-fed fat supplementation on growth and reproductive performance of developing beef heifers. The Professional Animal Scientist, 18, 38-43. doi: 10.15232/S1080-7446(15)31482-0

5. Deswysen, A.,G., Ellis, W.C., Pond, K.R., 1987. Interrelationship among voluntary intake, eating, and ruminating behaviour and ruminal motility of heifers fed corn silage. Journal of Animal Science 71, 835-841. doi: 10.2527/jas1987.643835x

6. Detmann, E., Valente, E.E.L., Batista, E.D., Huhtanen, P., 2014 An evaluation of the performance and efficiency of nitrogen utilization in cattle fed tropical grass pastures with supplementation. Livestock Science 162, 141-153. doi: 10.1016/j.livsci.2014.01.029

7. Dumont, B., Rossignol, N., Loucougaray, G., Carrere, P., Chadoeuf, J., Fleurance, G., Bonis, A., Farruggia, A., Gaucherand, S., Ginane, C., Louault, F., Marion, B., Mesléard, F., Yavercovski, N., 2012 When does grazing generate stable vegetation patterns in temperate pastures? Agriculture, Ecosystems, and Environment 153, 50-56. doi: 10.1016/j.agee.2012.03.003

8. Euclides, V.P.B., Lopes, C.F., Nascimento Junior, D., Silva, S.C., Difante, G.S., Barbosa, R.A., 2016 Steer performance on Panicum maximum (cv. Mombaça) pastures under two grazing intensities. Animal Production Science 56, 1849-1856. doi: 10.1071/AN14721

9. Gordon, J.G., 1965. The relationship between rumination and the amount of roughage eaten by sheep. The Journal of Agricultural Science, 64, 151-155. doi: 10.1017/S0021859600064698 
10. Hodgson, J., 1990. Grazing management: Science into practice, (Longman Scientific and Technical, Harlow).

11. Hodgson J., 1982. Ingestive Behaviour. In: J.D., Leaver (ed.), Herbage intake handbook. Hurley: The British Grassland Society, 111-138.

12. Koscheck, J.F.W., Zervoudakis, J.T., Hatamoto Z.L.K., Cabral, L.S., Oliveira, A.A., Benatti, J.M.B., Carvalho, D.M.G., Silva, R.P., 2013. Total digestible nutrient levels in supplements for finishing steers in the rainy season: nutritional characteristics and microbial efficiency. Revista Brasileira de Zootecnia, 42, 798-805. https://doi.org/10.1590/S1516-35982013001100006

13. Kunkle, W.E., Johns, J.T., Poore, M.H., Herd, D.B., 2000. Designing supplementation programs for beef cattle fed forage-based diets. Journal Animal Science 77, 1-11. doi:

10.2527/jas2000.00218812007700ES0012x

14. Lazzarini, I., Detmann, E., Valadares Filho, S.C., Paulino, M.F., Batista, E.D., Rufino, L.M.A., Reis, W.L.S., Franco, M.O., 2016. Nutritional performance of cattle grazing during rainy season with nitrogen and starch supplementation. Journal Animal Science, 29, 1120-1128. doi: 10.5713/ajas.15.0514

15. Littell, R.C., Milliken, G.A., Stroup, W.W., Wolfinger, R.D., Schabenberger, O., 2006 'SAS for Mixed Models'. (SAS Institute: Cary, N.C.)

16. Missio, R.L., Oliveira, M.D.S., Sforcini, M.P.R., Rennó, F.P., Júnior, J.E.F., Elejalde, D., Ferrari, V.B., Abud, G.C., 2012. Digestion of feed fractions and intake of heifers fed hydrolyzed sugarcane stored for different periods. Revista Brasileira de Zootecnia, 41, 1737-1746. doi: 10.1590/S151635982012000700025

17. Myers, W.D., Ludden, P.A., Nayigihugu, V., Hess, B.W., 2004. Technical note: a procedure for preparation and quantitative analysis of samples for titanium dioxide. Journal of Animal Science, 82, 179-193. doi: $10.2527 / 2004.821179 x$

18. Moraes, E.H.B.K., Paulino, M.F., Moraes, K.A.K., Valadares Filho, S.C., Detmann, E., Couto, V.R.M., 2017. Supplementation strategies for grazing beef cattle during the rainy-dry transition period. Semina: Ciências Agrárias, 38, 895-908. doi: 10.5433/1679-0359.2017v38n2p895

19. Mott, G.O., Lucas, H.L., 1952. The design conduct and interpretation of grazing trials on cultivated and improved pastures. In. International Grassland Congress, 1380-1395.

20. Penning, P.D., Rutter, S.M., 2004. Ingestive Behaviour. In: P.D., Penning (ed), Herbage Intake Handbook, The British Grassland Society, 151-175.

21. Poppi, D.P., McLennan, S.R., 1995. Protein and energy utilization by ruminants at pasture. Journal of Animal Science, 73, 278-290. Doi: 10.2527/1995.731278x

22. Schauer, C.S., Lardy, G.P., Slanger, W.D., Bauer, M.L., Sedivec, K.K., 2004. Self-limiting supplements fed to cattle grazing native mixed-grass prairie in the northern Great Plains. Journal of Animal Science 82, 298-306. doi: 10.2527/2004.821298x

23. Sniffen, C.J., Connor, J.D.O., Van Soest, P.J., Fox, D.G., Russell, J.B., 1992. A net carbohydrate and protein system for evaluating cattle diets: II. Carbohydrate and protein availability. Journal of Animal Science, 70, 3562-3577. doi: 10.2527/1992.70113562x 
24. Socreppa, L.M., Moraes, K.A.K., Oliveira, A.S., Batista, E.D., Drosghic, L.C.A.B., Botini, L.A., Paula, D.C., Stinguel, H., Bento, F.C., Moraes, E.H.B.K., 2017. Crude glycerine as an alternative energy feedstuff for beef cattle grazing tropical pasture. The Journal of Agricultural Science, 155, 839-846. doi: $10.1017 /$ S0021859617000119

25. Sollenberger, L.E., Moore, J.E., Allen, V.G., Pedreira, C.G.S., 2005. Reporting herbage allowance in grazing experiments. Crop Science, 45, 896-900, 2005.

26. Van Soest, P.J., Robertson, J.B., Lewis, B.A., 1991. Methods for dietary fiber, neutral detergent fiber and polysaccharides in relation to animal nutrition. Journal of Dairy Science, $74,3583-3597$. doi: 10.3168/jds.S0022-0302(91)78551-2

27. Williams, G.D., Beck, M.R., Thompson, L.R., Horn, G.W., Reuter, R.R., 2018. Variability in supplement intake affects performance of beef steers grazing dormant tallgrass prairie. The Professional Animal Scientist, 34, 364-371. doi: 10.15232/pas.2017-01720 